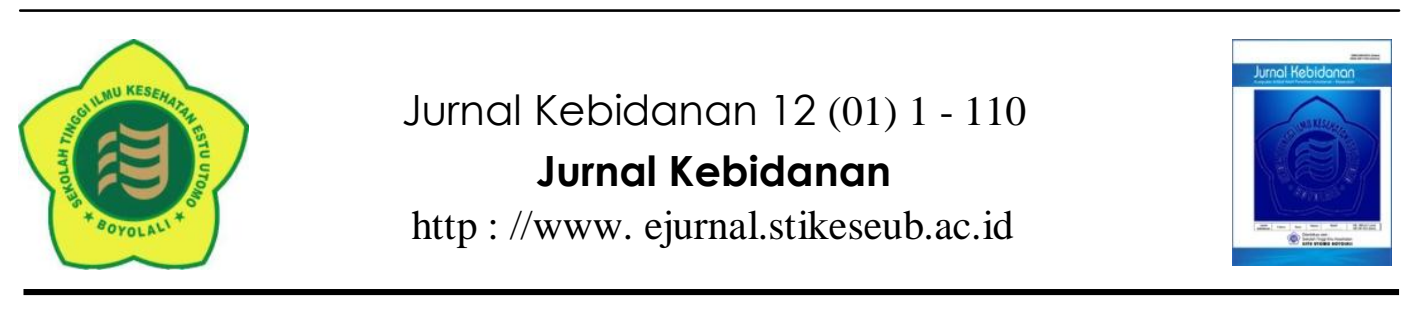

\title{
PENGARUH PRENATAL GENTLE YOGA TERHADAP TINGKAT KECEMASAN IBU HAMIL PRIMIGRAVIDA TRIMESTER III
}

\author{
Sri Hadi Sulistiyaningsih ${ }^{1)}$, Ana Rofika ${ }^{2)}$ \\ ${ }^{1)}$ Prodi Sarjana Kebidanan, Stikes Bakti Utama Pati Jl Ki Ageng Selo No. 15 Pati \\ ${ }^{2)}$ Prodi DIII Kebidanan, Stikes Bakti Utama Pati Jl Ki Ageng Selo No. 15 Pati \\ E-mail:mahira.hsp@gmail.com,_anna@stikesbup.ac.id
}

\begin{abstract}
ABSTRAK
Seorang wanita yang sedang berada dalam masa kehamilan sering mengalami banyak perubahan, baik itu perubahan secara fisik maupun perubahan secara psikologis. Perubahan itu akan terus terjadi selama 9 bulan masa kehamilannya. Kondisi psikologis dengan kecemasan dan depresi pada ibu hamil akan berpengaruh terhadap timbulnya penyakit serta komplikasi kehamilan dan persalinan, baik pada ibu maupun bayi. Prenatal gentle yoga yang dilakukan selama kehamilan merupakan sebagai salah satu bentuk pengobatan non farmakologi yang dapat membantu wanita fokus pada proses persalinan, bersiap untuk mentolerir nyeri, serta mengubah stres dan kecemasan menjadi energy. Tujuan penelitian ini adalah apakah ada pengaruh pelaksanaan prenatal gentle yoga terhadap tingkat penurunan kecemasan Ibu Hamil Primigravida Trimester III Dalam Menghadapi Persalinan. Jenis penelitian yang digunakan adalah Pre-eksperimental design dengan rancangan one group pretest posttest design dengan menggunakan satu kelompok subjek kemudian pengukuran dilakukan sebelum dan sesudah perlakuan. Populasi dan sampel sebanyak 30 orang dengan teknik sampling yaitu total sampling dan menggunakan uji statistik Uji Wilcoxon. Hasil penelitian menunjukkan bahwa $\mathrm{P}_{\text {value }} 0,000<0.05$ yang berarti bahwa ada pengaruh prenatal gentle yoga terhadap tingkat penurunan kecemasan ibu hamil primigravida trimester III dalam menghadapi proses persalinan.
\end{abstract}

Kata Kunci : Prenatal Gentle Yoga, Tingkat Kecemasan, Kehamilan

THE EFFECT OF GENTLE YOGA PRENATAL TO THE PREGNANT LEVEL OF PRIMIGRAVID TRIMESTER III PREGNANT WOMEN

\section{ABSTRACT}

A woman who is in pregnancy often experiences many changes, both physical changes and psychological changes. These changes will continue to occur during the 9 months of pregnancy. Psychological conditions with anxiety in pregnant women will affect the onset of complications of pregnancy and childbirth, both for mothers and babies. Prenatal gentle yoga that is done during pregnancy is one form of non-pharmacological treatment that can help women focus on labor, prepare to tolerate pain, and convert stress and anxiety into energy. The purpose of this study is whether there is an effect of the implementation of Prenatal Gentle Yoga on the Anxiety Level of Primigravida Trimester III Pregnant Women in the Face of Childbirth. The type of research used is Pre-experimental design with one group pretest-posttest design using one group of subjects and then measurements are taken before and after treatment. The population and sample were 30 pregnant women with a total sampling technique and using the Wilcoxon Test. The results showed that the level of anxiety before and after the implementation of prenatal gentle yoga there was a decrease in anxiety levels with a lower mean (mean) than before (25.4333) and after (19.5667). Statistical test results show that P-value 0,000 <0.05, which means that there is an effect of Prenatal Gentle Yoga on the Anxiety Level of Primigravida Trimester III Pregnant Women in Facing Childbirth.

Keyword : Prenatal Gentle Yoga, Anxiety Level, Pregnancy 


\section{PENDAHULUAN}

Seorang wanita yang sedang berada dalam masa kehamilan sering mengalami banyak perubahan, baik itu perubahan secara fisik maupun perubahan secara psikologis. Perubahan itu akan terus terjadi selama 9 bulan masa kehamilannya. Kondisi tersebut akan senantiasa menimbulkan rasa ketidaknyamanan pada fisik ibu hamil, ditambah pula dengan bayangan mengenai proses persalinan, bagaimana keadaan bayi dan kondisi bayinya setelah lahir nanti. Bayangan seperti itu umum muncul pada wanita hamil yang sebentar lagi menjalani persalinan. Kondisi seperti itulah yang dapat menimbulkan perasaan cemas pada ibu hamil terutama pada wanita yang baru pertama kali hamil (primigravida) (Fauziah, 2016).

Sebagian besar ibu yang sedang hamil sering mengalami ketakutan dan kecemasan menghadapi proses persalinan karena rasa sakit akibat persalinan. Hal tersebut dapat menimbulkan ketegangan jiwa dan fisik yang akan mengakibatkan otot dan persendian menjadi kaku yang tidak wajar. Stres atau kecemasan terkait dengan berbagai hasil kehamilan, rasa sakit, dan keluhan somatik lain yang sering terjadi dengan gangguan mood pada ibu hamil (Amy, et al, 2009).

Gangguan psikologis yang terjadi dapat berpengaruh buruk terhadap perkembangan janin dan mengakibatkan stres berkepanjangan yang dapat berefek pada terhambatnya perkembangan janin termasuk gangguan emosi setelah kelahiran, apabila tidak ditangani dengan baik meski dengan asupan nutrisi yang baik. Gangguan psikologis dapat meningkatkan risiko terjadinya komplikasi dalam persalinan, sehingga diperlukan pencegahan dengan beberapa metode untuk meringankan dan mempersiapkan ibu dalam menjaga kehamilan dan proses persalinan (Alfie, A, 2016).

Penelitian yang dilakukan oleh Astria (2009) menunjukkan, bahwa dari 158 responden, sebanyak 47,5\% ibu hamil tidak mengalami kecemasan dan $52,5 \%$ ibu hamil mengalami kecemasan. Proporsi ibu hamil yang mengalami kecemasan lebih tinggi dialami oleh kelompok kehamilan pertama (primigravida), yaitu sebanyak 66,2\% dibandingkan kelompok ibu hamil anak lebih dari satu (multigravida) yang mengalami kecemasan sebanyak 42,2\%.

Kecemasan atau ansietas adalah rasa khawatir, rasa takut yang tidak jelas sebabnya. kehamilan relatif umum,dengan sekitar 10-15\% dari semua wanita hamil mengalami beberapa tingkat kecemasan atau stres selama transisi besar inifase dalam kehidupan seseorang. Berdasarkan data ADAA (Anxiety and Depression Association of 
America) menyebutkan bahwa 52\% dari wanita yang telah hamil melaporkan peningkatan kecemasan atau depresi saat hamil (ADAA, 2015).

Kecemasan berkaitan dengan keadaan khawatir berupa rasa takut atau perasaan yang tidak pasti maupun tidak berdaya, serta keadaan emosi yang belum jelas akan objek spesifiknya. Pada kehamilan pertama ketakutan ini sering dirasakan terutama dalam menghadapi persalinan. Beban psikologi pada seorang wanita hamil, lebih banyak terjadi pada umur kehamilan trimester III. Wanita yang mengalami kecemasan sewaktu hamil akan lebih banyak mengalami persalinan abnormal bahkan dapat berkomplikasi pada kematian ibu dan janin (Salafas, E., Anisa, R., Rusita (2016).

Kondisi psikologis dengan kecemasan dan depresi pada ibu hamil akan berpengaruh terhadap timbulnya penyakit serta komplikasi kehamilan dan persalinan, baik pada ibu maupun bayi. Masalah kecemasan senantiasa muncul pada ibu primigravida maka dari itu masalah kecemasan tersebut harus segera diatasi, salah satunya dapat dilakukan dengan cara berolahraga. Olahraga pada ibu hamil bertujuan sebagai pengalihan perhatian, mengurangi kecemasan dan tekanan, menenangkan pikiran, meningkatkan kualitas tidur, membantu mengurangi konstipasi dan merangsang nafsu makan. Jenis olahraga yang dianjurkan adalah berjalan, bersepeda, berenang (Kamariyah, et al, 2014).

Selain jenis olahraga seperti berjalan, bersepeda dan berenang, menurut Indiarti (2009) saat ini di Indonesia sendiri sudah terdapat senam yang diperuntukan bagi ibu hamil salahsatunya yaitu dikenal dengan prenatal yoga. Senam prenatal yoga merupakan modifikasi dari senam yoga dasar yang disesuaikan gerakannya dengan kondisi ibu hamil. Yoga adalah suatu olah tubuh, pikiran dan mental yang sangat membantu ibu hamil dalam melenturkan persendian dan menenangkan pikiran terutama pada ibu hamil trimester II dan III. Gerakan dalam prenatal yoga dibuat dengan tempo yang lebih lambat dan menyesuaikan dengan kapasitas ruang gerak ibu hamil.

Yoga bukanlah sekedar menggerakkan atau bahkan melipat-lipat tubuh, tetapi yoga adalah sebuah filosofi saat pola pikiran sehari-hari kita, beserta seluruh keinginan, rasa khawatir, rasa takut, dan kebingungan yang kita miliki akhirnya dapat beristirahat. Yoga merupakan cara untuk mengatakan bahwa pada saat kita menyatu dengan diri sejati kita, kita akan mulai mengerti siapa diri kita dan tujuan keberadaan kita. Relaksasi yang dihasilkan dari latihan yoga dapat membuat ibu hamil menjalani 
hari-harinya dengan tenang, juga mampu mengurangi rasa takut akan proses persalinan. Senam yoga ini sangat diperlukan karena saat menghadapi persalinan ibu biasanya dilanda kecemasan dan panic. Prenatal yoga memiliki lima cara yaitu latihan fisik yoga, pernafasan (pranayama), position (mudra), meditasi, dan deep relaksasi yang dapat digunakan untuk mendapatkan manfaat selama kehamilan sehingga dapat membantu kelancaran dalam kehamilan dan kelahiran secara alami dan membantu memastikan bayi yang sehat. Unsur pada yoga yang dikatakan dapat membantu menurunkan kecemasan adalah pada bagian relaksasi dan meditasi.Yoga selama kehamilan dapat membantu wanita fokus pada proses persalinan, bersiap untuk mentolerir nyeri,serta mengubah stres dan kecemasan menjadi energy. (Aprilia, 2015).

Berdasarkan hasil penelitian yang dilakukan Beddoe et al (2009) :“ The effects of mindfulness-based yoga during pregnancy on maternal psychological and physical distress" dalam Bonura (2014) menunjukkan efek menguntungkan dari dilakukannya yoga pada wanita hamil yaitu dapat mengurangi stres dan kecemasan. Berdasarkan penelitian yang dilakukan oleh Fauziah (2016) bahwa ibu primigravida yang melakukan prenatal yoga menunjukkan penurunan kecemasan terkait proses persalinan, menambah keyakinan dan kemampuan diri terkait persalinan, serta mengurangi keluhan fisik. Menurut Urech, et al (2010) dalam Khalajzadeh (2012) yoga memiliki efek positif pada pengurangan stres, kecemasan, gangguan yang berkaitan dengan kehamilan danmeningkatkan indeks kesehatan mental perempuan.

Manfaat yoga yang tak kalah pentingnya yaitu memperkuat dan mempertahankan elastisitas otototot dinding perut, ligamentum, otot-otot dasar pangul dan otot paha bagian dalam, dengan demikian proses persalinan dapat dikuasai. Proses relaksasi akan sempurna dengan melakukan kontraksi dan relaksasi yang diperlukan untuk mengatasi ketegangan atau rasa sakit saat proses persalinan. Salah satu latihan menguatkan dan mempertahankan elastisitas adalah latihan menguatkan otot dasar panggul yang kegunaannya adalah melemaskan otot dasar panggul yang kuat dalam keadaan yang santai. Pada saat mengejan otot akan mengendur secara aktif sehingga kepala bayi akan keluar dengan mudah, dengan demikian akan memperlancar dalam proses persalinan (Irmawati, 2014).

Hasil penelitian Wijayanti (2014) tentang efektivitas senam hamil yoga terhadap penurunan kecemasan ibu hamil 
trimester III menunjukkan bahwa terdapat selisih rata-rata penurunan kecemasan dengan uji paired sampel test sebelum dan sesudah senam hamil yoga pada hari pertama sebanyak $6,86 \%$, pada hari kedua sebanyak 3,60\% dan pada hari ketiga sebanyak 1,46\% dengan analisis bivariat menunjukkan nilai $\mathrm{P}$ value $=0,000$, sehingga hal ini menunjukkan terdapat perbedaan penurunan kecemasan pada hari pertama dan hari ketiga sebelum dan sesudah diberikan senam hamil yoga. Perbedaan yang sangat jelas dalam penelitian Wijayanti (2014) adalah pengukuran kecemasan dengan menggunakan kuesiner DASS yang hanya terlihat berdasarkan kualitas tidur, sementara pada penelitian ini akan digunakan metode HRS-A dalam mengukur tingkat kecemasan sehingga diketahui tingkat kecemasan secara keseluruhan.

Berdasarkan latar belakang diatas,maka dapat dirumuskan masalah “Apakah Pelaksanaan Prenatal Gentle Yoga Berpengaruh Terhadap Tingkat Penurunan Kecemasan Ibu Hamil Primigravida Trimester III Dalam Menghadapi Persalinan”. Tujuan penelitian ini adalah untuk menganalisis pengaruh pelaksanaan prenatal gentle yoga terhadap penurunan kecemasan Ibu Hamil Primigravida Trimester III Dalam Menghadapi Persalinan.

\section{METODE}

Jenis penelitian yang digunakan adalah Pre-eksperimental design dengan rancangan one group pretest posttest design menggunakan satu kelompok subjek serta pengukuran dilakukan sebelum dan sesudah perlakuan. Ruang lingkup penelitian ini termasuk dalam lingkup kesehatan ibu hamil. Variabel independen adalah prenatal gentle yoga, sedangkan variabel dependen adalah kecemasan ibu hamil primigravida trimester III. Populasi dan sampel dalam penelitian ini adalah ibu hamil primigravida TM III di Rumah Sakit Miriam Kudus sebanyak 30 ibu hamil yang diambil dengan teknik total sampling. Instrumen yang digunakan dalam penelitian ini berupa lembar observasi menggunakan Hamilton Rating Scale for Anxiety (HRS-A) dengan modifikasi untuk mengetahui tentang tingkat kecemasan ibu hamil sebelum dan sesudah mengikuti kelas prenatal gentle yoga. Pengolahan data dilakukan dengan cara editing, coding, scoring dan tabulasi data. Pada penelitin ini uji yang dipakai menggunakan uji Shapiro-Wilk untuk mengetahui kenormalan data dengan hasil data berdistribusi tidak normal sehingga analisa data dilakukan dengan menggunakan $U j i$ Wilcoxon. 


\section{HASIL DAN PEMBAHASAN}

\section{Analisa Univariat}

Tabel 1.

Kecemasan Sebelum dan Sesudah Pelaksanaan Prenatal Gentle Yoga Pada Ibu Hamil Trimester III $(\mathrm{n}=30)$

\begin{tabular}{ccccccc}
\hline Kecemasan & Mean & Median & Modus & St.Deviasi & Min & Max \\
\hline Pre test & 25.4333 & 23.0000 & 22.00 & 5.19737 & 19.00 & 36.00 \\
\hline Post tes & 19.5667 & 19.0000 & 14.00 & 4.92484 & 14.00 & 30.00 \\
\hline
\end{tabular}

Berdasarkan tabel 1 diatas didapat tingkat kecemasan sebelum dan sesudah pelaksanaan prenatal gentle yoga menunjukkan bahwa ada penurunan tingkat kecemasan, terbukti dengan semakin rendahnya nilai rata-rata (mean) dari sebelum melakukan prenatal gentle yoga dan sesudah melakukan prenatal gentle yoga.

a. Tingkat Kecemasan Ibu Hamil sebelum melakukan prenatal gentle yoga

Hasil penelitian yang dilakukan pada 30 responden menunjukkan bahwa kecemasan sebelum pelaksanan prenatal yoga (pre test) dengan nilai rata-rata (mean) berada pada skor 25,4333, nilai tengah (median) berada pada skor 23, nilai yang sering muncul (modus) berada pada skor 22 dan nilai standar deviasi (SD) pada skor 5,19737, sedangkan nilai terendah yaitu berada pada skor 19 dan nilai tertinggi berada pada skor 36 .

b. Tingkat kecemasan ibu hamil sesudah melakukan prenatal gentle yoga

Hasil penelitian yang dilakukan pada 30 responden menunjukkan bahwa kecemasan sesudah pelaksanaan prenatal yoga (post test) dengan nilai rata-rata (mean) berada pada skor 19.5667, nilai tengah (median) berada pada skor 19, nilai yang sering muncul (modus) berada pada skor 14 nilai standar deviasi (SD) pada skor 4.92484, sedangkan nilai terendah yaitu berada pada skor 14 dan nilai tertinggi berada pada skor 30.

Berdasarkan data tersebut diperoleh bahwa ada penurunan tingkat kecemasan setelah melakukan prenatal gentle yoga dimana sebelumnya responden belum pernah mengikuti dan merasakan manfaat dari prenatal gentle yoga. 
Tabel 2. Selisih Hasil Pengaruh Prenatal Gentle Yoga Terhadap Tingkat Kecemasan Ibu Hamil Trimester III Dalam Menghadapi Persalinan $(n=30)$

\begin{tabular}{cc}
\hline $\begin{array}{c}\text { Sebelum-Sesudah Prenatal } \\
\text { Gentle Yoga }\end{array}$ & $\mathrm{N}$ \\
\hline Negative Ranks & 23 \\
\hline Positive Ranks & 3 \\
\hline Tiles & 4 \\
\hline Total & 30 \\
\hline
\end{tabular}

Berdasarkan tabel 2 menunjukkan bahwa responden yang mengalami penurunan skor kecemasan sebanyak 23 orang, responden dengan skor kecemasan tetap sebanyak 4 orang dan masih terdapat 3 responden yang mengalami peningkatan skor kecemasan karena rata-rata ibu hamil baru melakukan senam yoga kurang dari $3 x$ pertemuan.

\section{Analisa Bivariat}

Tabel 3. Pengaruh Prenatal Gentle Yoga Terhadap Tingkat Kecemasan Ibu Hamil Primigravida Trimester III Dalam Menghadapi Persalinan $(n=30)$

\begin{tabular}{cc}
\hline $\begin{array}{c}\text { Sebelum-sesudah Prenatal } \\
\text { Gentel Yoga }\end{array}$ & Hasil \\
\hline Asymp. Sig. (2-tailed) & 0.000 \\
\hline
\end{tabular}

Berdasarkan tabel 3 menunjukkan bahwa hasil uji hipotesis menunjukkan nilai sig $(-2$ tailed $)=$ 0,000 sehingga $0,000<0,05$ yang berarti ada pengaruh yang signifikan sebelum dan sesudah melakukan prenatal gentle yoga terhadap penurunan skor rata-rata kecemasan.

\section{Pembahasan}

1. Tingkat Kecemasan Ibu Hamil Sebelum Melakukan Prenatal Gentle Yoga

Hasil penelitian menunjukkan bahwa tingkat kecemasan ibu hamil trimester III sebelum melakukan prenatal gentle yoga rata-rata mengalami kecemasan ringan sampai dengan sedang. Faktor yang kemungkinan dapat mempengaruhi tingkat kecemasan ibu hamil adalah dari faktor usia kehamilan ibu yang rata-rata lebih dari 30 minggu dan semuanya termasuk dalam trimester III.

Dalam penelitian priharyanti, dkk (2018) dalam Hasuki (2007) meyatakan bahwa saat usia kehamilan menjelang persalinan maka akan muncul pertanyaan dan bayangan apakah dapat melahirkan normal, cara mengejan, apakah akan terjadi sesuatu saat melahirkan, atau apakah bayi lahir selamat, akan semakin sering muncul dalam benak ibu hamil. Rasa nyeri pada saat persalinan sudah sejak dulu menjadi pokok pembicaraan para wanita.

2. Tingkat Kecemasan Ibu Hamil Setelah Melakukan Prenatal Gentle Yoga

Hasil penelitian menunjukkan bahwa tingkat kecemasan ibu hamil trimester III setelah melakukan 
prenatal gentle yoga rata-rata mengalami penuruann tingkat kecemasan setelah beberapa kali mengikuti prenatal gentle yoga.

Menurut Sindhu (2013) dalam

penelitian Priharyanti

menyebutkan bahwa dari segi psikologis, dengan menggunakan teknik-teknik pernapasan yoga dapat menenangkan diri dan memusatkan pikiran. Selain itu, digunakan sebagai media self help yang akan membantu saat dilanda kecemasan dan ketakutan, atau saat perhatian tercerai berai atau saat perhatian terjebak dalam kemacetan lalu lintas pikiran.

Menurut Nurdiana dalam penelitian Haryanto, Miftah (2015), rasa cemas yang dialami oleh ibu hamil itu disebabkan karena meningkatnya hormon progesteron. Selain membuat ibu hamil merasa cemas, peningkatan hormon itu juga menyebabkan gangguan perasaan dan membuat ibu hamil cepat lelah. Hormon lain yang meningkat selama kehamilan adalah hormon adrenalin. Hormon adrenalin dapat menimbulkan disregulasi biokimia tubuh sehingga muncul ketegangan fisik pada ibu hamil seperti mudah marah, gelisah, tidak mampu memusatkan pikiran, ragu-ragu bahkan mungkin ingin lari dari kenyataan hidup.
Menurut Pieter dan Lubis (2010) ibu hamil akan mengalami bentuk-bentuk perubahan psikis yaitu perubahan emosional, cenderung malas, sensitif, gampang cemburu, minta perhatian lebih, perasaan tidak nyaman, depresi, stres, dan mengalami kecemasan.

Skor rata-rata kecemasan responden setelah mengikuti prenatal gentle yoga sebanyak 3 kali turun menjadi 25,4333 dengan nilai penurunan skor sebanyak 19.5667 skor. Hal ini sesuai dengan hasil penelitian yang dilakukan oleh Dian (2015), bahwa efek yoga terhadap kecemasan ibu hamil menunjukkan penurunan kecemasan yang signifikan yakni dengan nilai $\mathrm{p}$ value 0.003 . Penurunan kecemasan yang dipengaruhi oleh prenatal gentle yoga ini akibat dari rasanyaman yang dirasakan ibu hamil selama mengikuti kelas, sehingga akan membuat otototot rileks, pikiran tenang, dan meningkatkan kemampuan berkonsentrasi.

3. Pengaruh Prenatal Gentle Yoga Terhadap Tingkat Kecemasan Ibu Hamil Trimester III Dalam Menghadapi Persalinan

Berdasarkan hasil uji statistik, diperoleh hasil nilai signifikansi $p$ value sebesar 0,000. Artinya, bahwa nilai $p$ value $(0,000)<0,05$ maka Ho 
ditolak. Hal ini menunjukkan bahwa Ada Pengaruh Prenatal Gentle Yoga Terhadap Tingkat Kecemasan Ibu Hamil Primigravida Trimester III Dalam Menghdapai Persalinan.

Menurut hasil wawancara kepada responden mengenai kecemasan yang terjadi, kecemasan pada ibu timbul dikarenakan ini merupakan pengalaman hamil yang pertama kali dan memikirkan apakah dirinya mampu untuk melakukan persalinan, bagaimana keadaan bayinya nanti, dan apakah dirinya mampu merawat bayinya. Hasil penelitian ini menunjukkan bahwa prenatal gentle yoga dapat membantu ibu hamil dalam mengatasi keluhan selama trimester kehamilan, karena calon ibu lebih menjadi introspektif dan mulai banyak memikirkan dan mencemaskan proses persalinan, kelahiran, serta bayinya.

Hasil penelitian ini sejalan dengan penelitian yang dilakukan oleh Apriliani dan Wahyudi (2015) tentang "Pengaruh Yoga Prenatal Tehadap

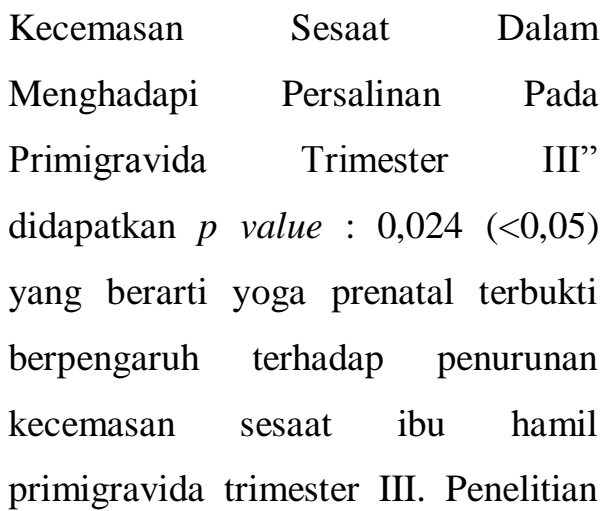

lain yang dilakukan oleh Hariyanto (2015) tentang "Pengaruh Senam Yoga Terhadap Tingkat Kecemasan Ibu Hamil Trimester III" dengan $p$ value : $0,002 \quad(<\quad 0,05)$ yang menunjukkan senam yoga berpengaruh terhadap penurunan tingkat kecemasan.

Menurut Krisnadi (2010) dalam penelitian Aryani, Aryani, R.Z, dkk (2018), gerakan senam hamil yoga terkandung efek relaksasi yang dapat menstabilkan emosi ibu hamil, sebab gerakan yoga memfokuskan perhatian pada ritme napas, mengutamakan kenyamanan serta keamanan dalam berlatih sehingga memberikan banyak manfaat.

Dalam penelitian Yohana, SW. (2018) bahwa ada pengaruh prenatal gentle yoga terhadap kecemasan ibu primigravida trimester III di Klinik Bidan Kita Klaten. Hal ini menunjukkan bahwa prenatal gentle yoga dapat membantu ibu hamil dalam mengatasi keluhan selama trimester III, khususnya keluhan tentang kecemasan menjelang persalinan.

Menurut Aprilia (2014) dalam penelitian Aryani, R.Z, dkk (2018) seorang ibu hamil yang memulai melakukan yoga pada trimester II akan menunjukkan penurunan yang sangat signifikan pada parameter 
dasar kecemasannya. Hal ini sesuai dengan hasil penelitian yang dilakukan oleh Dian (2015) dalam penelitian Aryani, R.Z, dkk (2018), bahwa efek yoga terhadap kecemasan ibu hamil menunjukkan penurunan kecemasan yang signifikan yakni dengan nilai $\mathrm{p}$ value 0.003 . Penurunan kecemasan yang dipengaruhi oleh prenatal gentle yoga ini akibat dari rasa nyaman yang dirasakan ibu hamil selama mengikuti kelas, sehingga akan membuat otot-otot rileks, pikiran tenang, dan meningkatkan kemampuan berkonsentrasi.

Latihan prenatal gentle yoga adalah sebuah treatmen fisik yang ternyata juga dapat memberikan efek psikologis karena memberikan efek relaksasi pada tubuh seseorang dan mempengaruhi beberapa aspek psikologis padaseseorang yang melakukannya dikatakan dapat membantu menurunkan kecemasan (Aprilia, 2014).

Menurut Babbar \& Shyken (2016), yoga adalah latihan pikiran dan tubuh yang mencakup latihan peregangan dan postur tubuh (asana) yang dikombinasikan dengan pernapasan dalam dan meditasi (pranayama). Yoga membutuhkan koordinasi gerakan tubuh dan napas dengan fokus pada kesadaran diri. Prenatal gentle yoga dapat membantu ibu hamil untuk mengendalikan pikiran, keinginan, dan reaksi terhadap stress. Prenatal gentleyoga ini terdiri dari tiga beberapa bagian, antara lain relaksasi, mengatur postur, dan olah napas. Dalam prenatal gentle yoga instruktur mendeskripsikan abaaba setiap gerakan, dilakukan dengan suara yang lembut, kalimat yang mudah dipahami, dan diiringi oleh musik dengan irama yang juga lembut. Pada saat sesi relaksasi, ibu hamil diminta untuk berbaring dan memejamkan mata, kemudian mengikuti imaginasi dan napas dalam yang diarahkan oleh instruktur.

Penelitian ini sejalan dengan penelitian yang dilakukan oleh Rusmita, Eli (2011) tentang pengaruh senam hamil yoga selama kehamilan terhadap kesiapan fisik dan psikologis pada ibu hamil trimester III. Hasil tersebut menyimpulkan bahwa, ibu hamil trimester III yang melakukan senam hamil yoga memiliki kesiapan fisik dan psikologis sebanyak 3,04 kali dibandingkan dengan ibu hamil trimester III yang tidak melakukan senam hamil yoga.

Menurut Jerath et al (2009) dalam penelitian Aryani, R.Z, dkk (2018), pernapasan dalam dapat mengaktifkan sistem saraf parasimpatis, terutama dengan meregangkan jaringan paru dan saraf 
vegal. Hal ini menyebabkan respon fisiologis ditandai dengan penurunan denyut jantung, tekanan darah, tingkat metabolisme, dan konsumsi oksigen. Pernapasan dalam juga meningkatkan neuroplastisitas, yang didefinisikan sebagai reorganisasi jalur saraf sebagai respon adaptif. Secara umum orang yang melakukan yoga akan mendapatkan banyak manfaat, salah satunya adalah menurunkan kecemasan pada ibu hamil.

\section{PENUTUP}

Berdasarkan hasil penelitian dapat disimpulkan bahwa ada pengaruh yang signifikan sebelum dan sesudah dilakukan prenatal gentle yoga dengan nilai sig $(-2$ tailed $)=0,000$ sehingga $0,000<0,05$ yang menunjukkan bahwa Ada Pengaruh Prenatal Gentle Yoga Terhadap Tingkat Kecemsan Ibu Hamil Primigravida Trimester III Dalam Menghadapi Persalinan. Diharapkan hasil penelitian ini dapat digunakan oleh bidan dalam memberikan asuhan kebidanan pada ibu hamil yang mengalami kecemasan menjelang persalinan sebagai salah satu bentuk pengobatan non farmakologi. Selain itu, kepada ibu hamil diharapkan senam yoga dapat dijadikan salah satu pilihan olahraga yang baik dan aman dalam mengatasi masalah yang dialami selama masa kehamilan, sehingga pada saat persalinan kondisi ibu bisa jauh lebih siap baik dari segi fisiologis maupun psikologis.

\section{DAFTAR PUSTAKA}

Alfie, A, (2016). Hubungan Senam Yoga dengan Kesiapan Fisik dan Psikologis Ibu Hamil dalam Menghadapi Persalinan di Kelas Antepartum Gentle Yoga Yogyakarta. Stikes Jendral Achmad Yani. Yogyakarta

Amy E. B, et al. (2009). The effects of mindfulness-based yoga during pregnancy on maternal psychological and physical distress. Journal of. Obstetric, Gynecologic, \& Neonatal Nursing 38.3 Posted 2009.

Anxiety and Depression Association of America. (2016). Pregnancy and Medication

Apriliani , R.A. (2015). Pengaruh Yoga Prenatal terhadap kecemasan sesaat dalam menghadapi persalinan pada primigravida trimester III Digalenia Mom and Baby Center Kota Bandung. Skripsi. Fakultas Psikologi Universitas Islam Bandung, Bandung

Ardiana, (2016.) Hubungan Senam Yoga Dengan Kesiapan Fisik dan Psikologis Ibu Hamil Dalam Mengadapi Persalinan di Aterpartum Gentle Yoga. Jurnal Terpadu Ilmu Kesehatan. Yogyakarta

Aryani R.Z, dkk. 2018. Pengaruh Pelaksanaan Prenatal Gentle Yoga Terhadap Kecemasan Menjelang Persalinan Pada Ibu Hamil Primigravida Trimester Iii Di Klinik Bidan Kita Klaten.

Astria, Y. (2009). Hubungan Karakteristik Ibu Hamil Trimester III dengan Kecemasan Dalam Menghadapi Persalian di Poliklinik Kebidanan dan Kandungan RSUPFatmawati.Jakarta 
Fakultas Kedokteran dan Ilmu Kesehatan, UIN Syarif Hidayatullah

Babbar, Shilpa, dkk. (2016). Yoga in Pregnancy Clinical Obstetrics and Gynecology.

Berliana, A., (2015). Kesiapan Fisik dan Psikologis Dalam Menghadapi Persalinan Pada Ibu Hamil Yang Melakukan Senam Yoga di Dothe Beauty and Fresh Sidoarjo

Bonura, Kimberlee Bethany. (2014). Yoga Mind While Expecting : The Psychological Benefits of Prenatal Yoga Practice. International Journal of Childbirth Education

Diana F, N, dkk (2015).Pengaruh Senam Yoga Terhadap Penurunan Tingkat Kecemasan Ibu Hamil Primigravida Trimester III. http://repository.poltekkessmg.ac.id/index.php?author $=\% 22$ nur+Diana+Fitriani\%22\&Search $=$ Search

Fauziah, Lestari. (2016). Efektivitas latihan yoga prenatal dalam menurunkan kecemasan pada ibu primigravida trimester III. Bandung : Universitas Padjajaran

Hariyanto, Miftah. 2015. Pengaruh Senam Yoga Terhadap Tingkat Kecemasan Ibu Hamil Trimester Iii Di Praktik Bidan Mandiri Kabupaten Boyolali.Universitas Muhammadiyah Surakarta

Indiarti, MT. 2009. Panduan lengkap kehamilan, persalinan dan perawatan bayi. (10thed). Yogyakarta: Diglossia media
Irmawati (2014). Tetap Tersenyum Saat Melahirkan. Penerbit : Media Pressindo

Khalazjadeh, Mona, et all. (2012). The Effect Of Yoga On Anxiety Among Pregnant Women In Second And Third Trimester Of Pregnancy. Scholars Research Library

Priharyanti W, dkk. 2018. Pengaruh Prenatal Yoga Terhadap Tingkat kecemasan Pada Ibu Primigravida Trimesterii Dan III Di Studio Qita Yoga Kecamatan Semarang Selatan Indonesia. http://ejournal.umm.ac.id/index.p hp/keperawatan/issue/view

Rusmita, Eli. (2011). Pengaruh senam hamil yoga selama kehamilan terhadap kesiapan fisik dan psikologis dalam menghadapi persalinan pada ibu hamil trimester III di RSIA Limijati Bandung. Tesis, Universitas Indonesia.

Salafas, E., Anisa, R., Rusita, V.I Efektifitas Hypno-EFT dan Pernafasan Yoga dalam Menurunkan Kecemasan Ibu Hamil di BPM Ny. Sri Kustinah. Jurnal Ilmiah Kebidanan 2016;7(2): 84-94

Yohana, SW. 2018. Hubungan Senam Yoga Prenatal Dengan Lamanya Proses Persalinan Kala II Pada Ibu Bersalin Di Bps Nengah Sriniati Kabupaten Mesuji Tahun $2017: 30-33$ 